\title{
24. SYNTHESIS OF MAGNETIC REMANENCE CORRELATION, LEG 155 ${ }^{1}$
}

\author{
S.M. Cisowski ${ }^{2}$
}

\begin{abstract}
Conventional magnetic stratigraphy was not possible due to the young age $(<780 \mathrm{ka})$ of the recovered sediments. Taking advantage of the exceptionally high sedimentation rates, however, we were able to successfully adopt several other less-utilized magnetostratigraphic techniques. Foremost among these was the identification of short periods of anomalous geomagnetic polarity (i.e., events and excursions) in the archive-half magnetic remanence record. Another was the recognition of distinctive patterns in magnetic remanence intensity, which seemingly could be correlated between distant sites. The third method, the identification of sequential secular variation cycles, probably cannot provide unequivocal time correlations from site to site. Nevertheless, it should be useful in determining variation in "true" sedimentation rates within individual lithostratigraphic units. The fourth technique involves the recognition of distinctive changes in remanence inclination, which are less pronounced but of longer duration than geomagnetic excursions.
\end{abstract}

\section{EXCURSIONS AND EVENTS}

In Holes 930B and 930C, an anomalous zone of remanence direction and intensity was detected beginning at 85 and 89 mbsf, approximately $45 \mathrm{~m}$ above a biostratigraphic datum of $\sim 40 \mathrm{ka}$. This anomalous zone extended over more than $2 \mathrm{~m}$, and was characterized by a rapid shift of inclination to high positive values (corresponding to the apparent motion of the pole toward the site), associated with a sharp increase in remanence intensity (see Fig. 18, "Site 930" chapter, this volume).

The Lake Mungo Excursion, which was first identified from early hominid Australian fireplaces dated at $\sim 30 \mathrm{ka}$, consists of a large increase in field strength, and migration of the apparent geomagnetic pole toward the equatorial eastern Pacific (Merrill and McElhinny, 1983). Because of its relationship to the biostratigraphic datum, and the equivalence of its remanence record, we identified the Site 930 excursion as the Lake Mungo Excursion. Remanence anomalies of the same character, and of generally similar stratigraphic position, were recorded in six other Leg 155 sites (Table 1). Although their records were often not as complete, we think that many, if not all, of these other anomalous polarity zones correspond to the same $\sim 30-\mathrm{ka}$ time horizon.

A second, older excursion was recorded beginning just below a carbonate-rich interval in three holes from Sites 942 and 946 (Table 1). The remanence behavior included a prolonged shift to high positive inclinations, coincident with a drop in remanence intensity. The Blake Event, which is characterized by low field intensity and pole positions generally in close proximity to our site (Tric et al., 1991), is an obvious candidate as a corresponding previously described geo-

'Flood, R.D., Piper, D.J.W., Klaus, A., et al., 1995. Proc. ODP, Init. Repts., 155: College Station, TX (Ocean Drilling Program).

${ }^{2}$ Department of Geological Sciences, University of California at Santa Barbara, Santa Barbara, CA 93105 , U.S.A.
Table 1. Excursions of the geomagnetic field recorded during Leg 155.

\begin{tabular}{|c|c|c|}
\hline Hole, core, section & $\begin{array}{l}\text { Depth } \\
\text { (mbsf) }\end{array}$ & Comments \\
\hline \multicolumn{3}{|l|}{ Lake Mungo ( 30 ka) } \\
\hline $930 \mathrm{~B}-10 \mathrm{H}-3$ & $85.2-87.5$ & \\
\hline $930 \mathrm{C}-7 \mathrm{H}-3$ & $89.3-90.5$ & Tilted beds, possible slump \\
\hline $931 \mathrm{~B}-9 \mathrm{H}-7$ and $-\mathrm{CC}$ & 76.5 & Top only (bottom of core) \\
\hline $932 \mathrm{~A}-3 \mathrm{H}-7$ and $-\mathrm{CC}$ & $24.9-25.9$ & Bottom of core \\
\hline $933 \mathrm{~A}-9 \mathrm{H}-8$ & $81.5-83.0$ & Top only (bottom of core) \\
\hline $938 \mathrm{~A}-16 \mathrm{X}-3$ and -4 & $144.4-146$ & XCB core \\
\hline $942 \mathrm{~A}-2 \mathrm{H}-7$ & $11-12$ & \\
\hline $942 \mathrm{C}-2 \mathrm{H}-4$ & $9-10$ & Inclination distorted \\
\hline $946 \mathrm{~A}-11 \mathrm{H}-7$ & $101.5-101.8$ & Bottom only \\
\hline \multicolumn{3}{|l|}{ Blake $(\sim 105 \mathrm{ka})$} \\
\hline $942 \mathrm{~A}-5 \mathrm{H}-7$ to $-6 \mathrm{H}-1$ & $41.0-42.2$ & \\
\hline $942 \mathrm{C}-3 \mathrm{H}-2$ & $36.0-38.7$ & Bottom only \\
\hline $946 \mathrm{~A}-15 \mathrm{H}-3$ & $133.2-134.0$ & \\
\hline
\end{tabular}

magnetic event. The Blake Event ( $\sim 105 \mathrm{ka})$ and the Lake Mungo Excursion are the only geomagnetic episodes from within the Brunhes polarity chron that appear to have occurred on a global scale (Stupavsky and Gravenor, 1984).

\section{REMANENCE INTENSITY PATTERNS}

Changes in remanence intensity with depth can reflect temporal variations in geomagnetic field strength, or reflect changes in the nature or provenance of the sediment. While plotting the downhole variations of remanence intensity for the Leg 155 holes, we noticed a distinctive pattern of remanence intensity, associated with the stratigraphic intervals immediately above and below the Lake Mungo Excursion (Table 2). This pattern consists of an intensity low (L) immediately below the Lake Mungo horizon, and five intensity peaks (A-E) above the excursion (see Fig. 15, "Site 933" chapter; Fig. 13, "Site 938 " chapter; and Fig. 20, "Site 942" chapter, this volume). The pattern is broadly similar to the geomagnetic intensity pattern for 10 $40 \mathrm{ka}$ as recorded in cores from the Mediterranean Sea (Tric et al., 1992). Seismic correlation indicates that these intensity features occur primarily within the Channel 5, Yellow, and Blue Channel-levee systems. Ages associated with corresponding intensity features in the Mediterranean cores are indicated in Table 2. A second, younger set of intensity features (1-3) can be identified in sediments equivalent to the Aqua and younger levee systems.

\section{SECULAR VARIATION}

Many clay intervals within the Leg 155 APC cores displayed oscillations in inclination, declination, and/or remanence intensity that appear to correspond to geomagnetic secular variation. In some holes both long wavelength (several meters) and short wavelength $(<\mathrm{l})$ cyclicities were apparent (Table 3). Our original expectation was that the long period cycles corresponded to the $\sim 1500$-yr cycles recorded in lake sediments, whereas the short cycles were related to the $\sim 500$ 
Table 2. Remanence intensity patterns.

\begin{tabular}{lcccc}
\hline Amazon to Aqua intervais: & & & \\
Hole & $\begin{array}{r}\text { Peak \#1 } \\
\text { (mbsf) }\end{array}$ & $\begin{array}{r}\text { Peak \#2 } \\
\text { (mbsf) }\end{array}$ & $\begin{array}{r}\text { Peak \#3 } \\
\text { (mbsf) }\end{array}$ & Comments \\
\hline 935A & 4 & 12 & 28 & \\
$939 \mathrm{~B}$ & 7 & 42 & & \\
$940 \mathrm{~A}$ & 16 & 47 & 156 & \\
$943 \mathrm{~A}$ & 5 & 35 & 97 & Sparse data, \#1 poorly defined \\
$944 \mathrm{~A}$ & 45 & 82 & 37 & \\
$946 \mathrm{~A}$ & 3 & 28 & 37 & \\
\hline
\end{tabular}

Blue to Channel 5 intervals:

\begin{tabular}{|c|c|c|c|c|c|c|}
\hline Hole & $\begin{array}{c}\text { Peak A } \\
\text { (mbsf) }\end{array}$ & $\begin{array}{l}\text { Peak B } \\
\text { (mbsf) }\end{array}$ & $\begin{array}{l}\text { Peak C } \\
\text { (mbsf) }\end{array}$ & $\begin{array}{l}\text { Peak D } \\
\text { (mbsf) }\end{array}$ & $\begin{array}{l}\text { Peak E } \\
\text { (mbsf) }\end{array}$ & $\underset{\text { (mbsf) }}{\mathrm{L}}$ \\
\hline $930 \mathrm{C}$ & 56 & 62 & 73 & 77 & 85 & $90-95$ \\
\hline $931 \mathrm{~B}$ & 10 & 28 & 45 & 52 & 57 & $80-92$ \\
\hline $932 \mathrm{~A}$ & 5 & 8 & 14 & 18 & 22 & $26-28$ \\
\hline $933 \mathrm{~A}$ & 57 & 64 & 70 & 76 & 78 & $84-89$ \\
\hline $938 \mathrm{~A}$ & 10 & 24 & 60 & 76 & 137 & $150-162$ \\
\hline $942 \mathrm{~A}$ & 3 & 5 & 9 & 10 & 11 & \\
\hline
\end{tabular}

Probable

age (Tric et

al., 1992) $10 \mathrm{ka} \quad 17 \mathrm{ka} \quad 26 \mathrm{ka} \quad ? \quad ? \quad 39-40 \mathrm{ka}$

Table 3. Intervals of secular variation.

\begin{tabular}{|c|c|c|c|c|}
\hline Hole & $\begin{array}{c}\text { Interval } \\
\text { (mbsf) }\end{array}$ & Parameter & $\begin{array}{l}\text { Wavelength } \\
\text { (m) }\end{array}$ & Amplitude \\
\hline $930 \mathrm{C}$ & $39-76$ & Inclination & 2.2 & $7^{\circ}-20^{\circ}$ \\
\hline \multirow[t]{2}{*}{$931 \mathrm{~A}$} & $1-15$ & Declination & 0.75 & $\sim 10^{\circ}$ \\
\hline & $30-41$ & Declination & 3.1 & $10^{\circ}-20^{\circ}$ \\
\hline \multirow[t]{3}{*}{$932 \mathrm{~B}$} & $3-11$ & Declination & 1.1 & $10^{\circ}-25^{\circ}$ \\
\hline & $18-22$ & Declination & 0.8 & $\sim 15^{\circ}$ \\
\hline & $31-44$ & Declination & 1.4 & $15^{\circ}-25^{\circ}$ \\
\hline $933 \mathrm{~A}$ & $56-68$ & Inclination & 3.0 & $20^{\circ}-30^{\circ}$ \\
\hline $934 A$ and $-B$ & $10-50$ & Inclination & 25.0 & $\sim 30^{\circ}$ \\
\hline \multirow[t]{2}{*}{$935 \mathrm{~A}$} & $13-23$ & Inclination & 2.0 & $\sim 20^{\circ}$ \\
\hline & $36-42$ & Declination and inclination & 1.2 & $10^{\circ}-20^{\circ}$ \\
\hline \multirow[t]{4}{*}{$936 \mathrm{~A}$} & $7-13$ & Declination & 0.8 & $10^{\circ}-15^{\circ}$ \\
\hline & $7-15$ & Inclination & 1.2 & $5^{\circ}-10^{\circ}$ \\
\hline & $26-30$ & Inclination & 1.3 & $5^{\circ}-10^{\circ}$ \\
\hline & $64-66$ & Declination and inclination & 0.25 & $2^{\circ}-10^{\circ}$ \\
\hline 937B & $1-45$ & Inclination & 1.3 & $7^{\circ}-20^{\circ}$ \\
\hline \multirow[t]{3}{*}{$938 \mathrm{~A}$} & $1-50$ & Inclination & 5.4 & $20^{\circ}-30^{\circ}$ \\
\hline & $1-50$ & Inclination & 1.5 & $5^{\circ}-20^{\circ}$ \\
\hline & $70-78$ & Declination & 0.5 & $5^{\circ}-10^{\circ}$ \\
\hline \multirow[t]{4}{*}{$939 \mathrm{~A}$} & $1-35$ & Inclination & $8-20$ & $\sim 45^{\circ}$ \\
\hline & $1-35$ & Inclination & 1.75 & $5^{\circ}-15^{\circ}$ \\
\hline & $20-60$ & Declination & 13.0 & $\sim 80^{\circ}$ \\
\hline & $70-80$ & Declination & 3.3 & $\sim 20^{\circ}$ \\
\hline \multirow[t]{3}{*}{$940 \mathrm{~A}$} & $5-30$ & Inclination & $0.9-1.2$ & $\sim 5^{\circ}$ \\
\hline & $42-55$ & Inclination & 0.5 & $\sim 5^{\circ}$ \\
\hline & $12-20$ & Declination & 1.0 & $5^{\circ}-10^{\circ}$ \\
\hline $941 \mathrm{~A}$ & $1-5$ & Inclination & 0.4 & $5^{\circ}-10^{\circ}$ \\
\hline $942 A$ and $-B$ & $1-15$ & Inclination & $0.5-0.7$ & $5^{\circ}-15^{\circ}$ \\
\hline $942 \mathrm{C}$ & $67-72$ & Declination & 0.5 & $\sim 10^{\circ}$ \\
\hline \multirow[t]{2}{*}{$943 \mathrm{~A}$} & $0-4$ & Declination and inclination & 0.4 & $\sim 10^{\circ}$ \\
\hline & $34-37$ & Declination and inclination & 0.4 & $5^{\circ}-15^{\circ}$ \\
\hline \multirow[t]{3}{*}{$944 \mathrm{~A}$ and $-\mathrm{C}$} & $1-37$ & Declination and inclination & $0.25-0.5$ & $5^{\circ}-10^{\circ}$ \\
\hline & $63-68$ & Declination and inclination & $0.25-0.5$ & $5^{\circ}-10^{\circ}$ \\
\hline & $75-80$ & Declination and inclination & $0.25-0.5$ & $5^{\circ}-10^{\circ}$ \\
\hline 946A & $10-13$ & Declination and inclination & 0.25 & $5^{\circ}-10^{\circ}$ \\
\hline
\end{tabular}

Table 4. Inclination shifts (Blue to Purple Channel-levee System).

\begin{tabular}{cccc}
\hline Hole & $\begin{array}{c}\text { Top } \\
\text { (mbsf) }\end{array}$ & $\begin{array}{c}\text { Bottom } \\
\text { (mbsf) }\end{array}$ & Range \\
\hline $930 \mathrm{C}$ & 64.5 & 72.5 & $-30^{\circ}$ to $+26^{\circ}$ \\
$937 \mathrm{~B}$ & 24.0 & 27.5 & $-60^{\circ}$ to $0^{\circ}$ \\
$938 \mathrm{~A}$ & 15.0 & 46.0 & $-40^{\circ}$ to $+34^{\circ}$ \\
\hline
\end{tabular}

Virtual Geomagnetic Pole (VGP) loops derived from observatory records and archeomagnetic studies. However, where both cycles could be seen in the same hole, some of the longer wavelengths were six to 12 times longer than the shorter ones. A possible explanation is that the nondipole sources that are thought to be responsible for short period secular variation move past an equatorial site much faster than they pass a moderate- to high-latitude site. This would be the case if all nondipole sources on the surface of the Earth's core have constant angular velocity. A more accurate assessment of the actual time periods represented by these two wavelengths should result from postcruise isotopic and radiocarbon studies.

\section{INCLINATION SHIFTS}

In general, inclination and declination cycles and trends could not be correlated between Leg 155 cores. Apparently, core disturbance, tilting of beds, unevenness in core cutting, and other unresolved causes produced inclination and declination shifts that often obscured real shifts in the geomagnetic field orientation. A possible exception was an interval of inclination cycles recorded in Holes 930C, 937B, and $938 \mathrm{~A}$, where the downcore trend was from high negative to moderate positive values over five wavelengths. In all three holes, this interval apparently corresponded to the seismic boundary between the Blue and Purple Channel-levee systems, suggesting this feature may be used as a stratigraphic marker to refine seismic correlation (Table 4).

\section{REFERENCES*}

Merrill, R.T., and McElhinny, M.W., 1983. The Earth's Magnetic Field: Its History, Origin, and Planetary Perspective: London (Academic Press).

Stupavsky, M., and Gravenor, C.P., 1984. Paleomagnetic dating of Quaternary sediments: a review. In Mahaney, W.C. (Ed.), Quaternary Dating Methods: Amsterdam (Elsevier).

Tric, E., Laj, C., Valet, J.-P., Tucholka, P., Paterne, M., and Guichard, F., 1991. The Blake geomagnetic event: transition geometry, dynamical characteristics and geomagnetic significance. Earth Planet. Sci. Lett., 102:1-13.

Tric, E., Valet, J.-P., Tucholka, P., Paterne, M., Labeyrie, L., Guichard, F., Tauxe, L., and Fontugne, M., 1992. Paleointensity of the geomagnetic field during the last 80,000 years. J. Geophys. Res., 97:9337-9351.

\footnotetext{
*Abbreviations for names of organizations and publications in ODP reference lists follow the style given in Chemical Abstracts Service Source Index (published by American Chemical Society).
} 